7. Reprod. Fert. (1966) 11, 181-184

\title{
EFFECTS OF AGE AND STRAIN OF FEMALE, AND OF ETHYLENE DICHLORIDE EXTRACTED WHEAT GERM OIL ON REPRODUCTION IN MINK (MUSTELA VISON)*
}

\author{
W. RICHARD DUKELOW $\dagger$ \\ University of Minnesota, Grand Rapids
}

(Received 11th May 1965)

\begin{abstract}
Summary. One hundred and sixty female mink of four colour strains (Pearl, Cameo, Dawn Pastel and Violet) were assigned to eight groups according to age and colour. One-half of each group received wheat germ oil extracted with ethylene dichloride, while control mink received corn oil supplemented with mixed tocopherols. Mean performance data for the control and treated groups respectively were as follows: days from first attempted mating until actual first mating, 3.0 and $2 \cdot 1$; conception rate, 66.3 and $60.0 \%$; young born/pregnant female, 2.29 and 2.45 ; weight of young at 3 weeks of age, females 93.6 and $95.5 \mathrm{~g}$, and males 101.7 and $105 \cdot 1 \mathrm{~g}$. Differences between control and treated groups were not statistically significant. Highly significant differences were observed between strains for conception rate, number of male and female young and total young/pregnant female. A significant interaction was noted between wheat germ oil treatment and strain in the number of days required to achieve mating. Previous reproductive history of the females (parous or non-parous) had little effect on the characteristics studied.
\end{abstract}

\section{INTRODUCTION}

Reproduction in the common mink (Mustela vison) is characterized by failure of many females to mate, failure to conceive if they do mate and small litter size accompanied by high embryonic mortality if they conceive. These characteristics have been surveyed in the classic studies of Hansson (1947) and Enders (1952). The reproductive process is further complicated by the phenomenon of delayed implantation resulting in wide variations in gestation length between females. Therefore gestation length is affected both by the time of season that copulation occurs and by the size of the litter carried (Hansson, 1947; Enders, 1952).

The role of ethylene dichloride extracted wheat germ oil (EDC-WGo), although used by mink ranchers for over 25 years, has never been subjected to a controlled test in this species. EDC-WGO significantly improved reproduction in repeat breeder dairy cattle (Marion, 1962) and sheep (Dukelow \& Matalamaki, 1963).

* Paper No. 5389, Scientific Journal Series, Minnesota Agricultural Experiment Station.

$\uparrow$ Present address: Department of Biochemistry, University of Georgia, Athens, Georgia, U.S.A. 
A 28-carbon straight chain saturated alcohol (octacosanol) has been isolated from ethylene dichloride extracted wheat germ oil (Levin, Collins, Varner \& Mosser, 1962). This substance, as well as the oil from which it is derived, exerts a significant gonadotrophic response when tested by the Dorfman chick-comb growth technique (Levin, 1963).

The objectives of the present study were to determine reproductive performance in: (1) female mink of four colour strains, (2) in parous and non-parous females, and (3) in untreated mink and in mink receiving EDC-WGO.

\section{EXPERIMENTAL PROCEDURE}

One hundred and sixty breeding females were allotted to eight groups according to age and strain (colour phase). The four strains studied were the Pearl (pp bpbp alal), Cameo (alal $\mathrm{bm}^{\mathrm{H}} \mathrm{bm}^{\mathrm{H}}$ ), Dawn Pastel (bb bsbs) and Violet (pp alal bmbm). Half of the females in each of the parous and non-parous groups were assigned at random to the control group and the remainder to the experimental group. All mink received a standard ration consisting of $55 \%$ meat, $12 \%$ cereal and $33 \%$ water supplemented with vitamin A (1,560,000 i.u.) ton of dry feed) and a bacterial-fungal enzyme (Nopco Chemical Co., Harrison, New Jersey, 4 lbs/ton of dry feed). Beginning 10th February 1963, 4 weeks before the breeding season, the experimental ration was supplemented with a quantity of EDC-WGO calculated to provide $5 \mathrm{ml}$ wheat germ oil/seven mink daily. The control ration received an identical quantity of corn oil fortified with mixed tocopherols at a level equivalent to that found in the wheat germ oil. The feeding of the oil supplements continued until 18th April 1963.

Matings were attempted on $25 \%$ of the breeding herd each day, starting on 10th March. The same number of females in the control and treated groups were tried daily. Similarly, an equal number of females of each strain (in control and treated groups) were tried daily. The ratio of females to males was $8: 1$ and equal numbers of females in each strain were bred to each male. Half of the males were 2 years old and the remaining one-half were kits.

The first kits were born on 2nd May 1963. Because of the excitability and cannibalistic nature of lactating females, the number and weights of young were recorded at 3 weeks of age instead of at birth. The measurements taken included: (1) days to achieve mating (number of days from when mating was first attempted until copulation was achieved), (2) conception rate (number of females producing a litter/females mated), (3) numbers and mean weights of live male and female kits/pregnant female and (4) total live kits/pregnant female. All data were treated by analysis of variance.

\section{RESULTS AND DISCUSSION}

Mean values for all characteristics studied are shown in Table 1 and mean squares of the analysis of variance in Table 3 . There was a significant difference $(P<0.05)$ between the two age groups in the number of male kits alive at 3 weeks of age/pregnant female. The older females tended to have larger litters.

Distinct differences were noted between colour strains in reproductive ability. These differences were highly significant $(P<0 \cdot 01)$ for conception rate, 
TABLE 1

REPRODUCTIVE CHARAGTERISTICS OF MINK (Mustela vison)

\begin{tabular}{|c|c|c|c|c|c|c|c|c|}
\hline \multirow{2}{*}{ Characteristic } & \multicolumn{2}{|c|}{ Treatment } & \multicolumn{2}{|c|}{ Age of female } & \multicolumn{4}{|c|}{ Strain } \\
\hline & Control & EDC-WGO & roung & Aged & Pearl & Cameo & Dawn Pastel & $l$ Violet \\
\hline No. of females & 80 & 80 & 80 & 80 & 92 & 20 & 28 & 20 \\
\hline Days to achieve mating & $3 \cdot 0$ & $2 \cdot 1$ & $2 \cdot 7$ & $2 \cdot 5$ & $2 \cdot 4$ & 1.9 & $4 \cdot 1$ & $1 \cdot 8$ \\
\hline Conception rate (\%) & $56 \cdot 3$ & $60 \cdot 0$ & $56 \cdot 3$ & $60 \cdot 0$ & $53 \cdot 3$ & $60 \cdot 0$ & $85 \cdot 7$ & $40 \cdot 0$ \\
\hline $\begin{array}{l}\text { Average No. of male kits } \\
\text { at } 3 \text { weeks/pregnant } \\
\text { female }\end{array}$ & $1 \cdot 29$ & $1 \cdot 34$ & 1.05 & 1.58 & 1.09 & $1 \cdot 30$ & $2 \cdot 50$ & 0.70 \\
\hline $\begin{array}{l}\text { Average No. of female } \\
\text { kits at } 3 \text { weeks/preg- } \\
\text { nant female }\end{array}$ & 1.00 & $1 \cdot 11$ & 0.98 & $1 \cdot 14$ & 0.92 & $1 \cdot 15$ & 1.82 & 0.50 \\
\hline $\begin{array}{l}\text { Total kits at } 3 \text { weeks/ } \\
\text { pregnant female }\end{array}$ & $2 \cdot 29$ & $2 \cdot 45$ & $2 \cdot 03$ & $2 \cdot 72$ & $2 \cdot 01$ & $2 \cdot 45$ & $4 \cdot 32$ & $1 \cdot 20$ \\
\hline $\begin{array}{l}\text { Average weight of male } \\
\text { kits at } 3 \text { weeks }(\mathrm{g})\end{array}$ & $101 \cdot 7$ & $105 \cdot 2$ & $100 \cdot 7$ & $105 \cdot 4$ & $102 \cdot 4$ & $104 \cdot 0$ & $101 \cdot 5$ & $112 \cdot 9$ \\
\hline $\begin{array}{l}\text { Average weight of female } \\
\text { kits at } 3 \text { weeks (g) }\end{array}$ & $93 \cdot 6$ & 95.5 & $94 \cdot 6$ & $94 \cdot 4$ & $96 \cdot 4$ & $92 \cdot 2$ & $91 \cdot 8$ & $95 \cdot 6$ \\
\hline
\end{tabular}

TABLE 2

MEAN NUMBER OF DAYS TO ACHIEVE MATING

\begin{tabular}{l|c|c}
\hline \multicolumn{1}{c|}{ Strain } & $\begin{array}{c}\text { Control } \\
\text { (days) }\end{array}$ & $\begin{array}{c}\text { EDC-wGo } \\
(\text { days })\end{array}$ \\
\hline Pearl & $2 \cdot 6$ & $2 \cdot 2$ \\
Cameo & 1.3 & $2 \cdot 4$ \\
Dawn Pastel & $5 \cdot 2$ & 2.9 \\
Violet & 3.3 & 0.3 \\
\hline
\end{tabular}

EDC-WGO $=$ ethylene dichloride extracted wheat germ oil.

TABLE 3

MEAN SQUARES FOR FACTORS STUDIED

\begin{tabular}{|c|c|c|c|c|c|c|c|c|}
\hline \multirow[b]{2}{*}{$\begin{array}{l}\text { Source of } \\
\text { variation }\end{array}$} & \multirow[b]{2}{*}{ d.f. } & \multicolumn{7}{|c|}{ Mean squares } \\
\hline & & $\begin{array}{c}\text { Days to } \\
\text { achieve mating }\end{array}$ & $\begin{array}{l}\text { Conception } \\
\text { rate }\end{array}$ & $\begin{array}{l}\text { Female kits } \\
\text { at } 3 \text { weeks }\end{array}$ & $\begin{array}{l}\text { Male kits } \\
\text { at } 3 \text { weeks }\end{array}$ & $\begin{array}{l}\text { Total kits } \\
\text { at } 3 \text { weeks }\end{array}$ & $\begin{array}{c}\text { Male kit } \\
w t\end{array}$ & $\begin{array}{c}\text { Female kit } \\
w t\end{array}$ \\
\hline $\begin{array}{l}\text { Total } \\
\text { Treatment }(\mathrm{T}) \\
\text { Colour strain }(\mathrm{G}) \\
\text { Age }(\mathrm{A}) \\
\mathrm{T} \times \mathrm{C} \\
\mathrm{T} \times \mathrm{A} \\
\mathrm{C} \times \mathrm{A} \\
\mathrm{T} \times \mathrm{A} \times \mathrm{G} \\
\text { Error }\end{array}$ & $\begin{array}{r}159 \\
1 \\
3 \\
1 \\
3 \\
1 \\
3 \\
3 \\
144\end{array}$ & $\begin{array}{c}29 \cdot \overline{75} \\
9 \cdot 11 \\
1 \cdot 40 \\
40 \cdot 55 * * \\
12 \cdot 67 \\
24 \cdot 92 \\
9 \cdot 64 \\
12 \cdot 01\end{array}$ & $\begin{array}{l}0 . \overline{0} \\
1 \cdot 00^{* *} \\
0.05 \\
0 \cdot 13 \\
0 \cdot 17 \\
0 \cdot 13 \\
0.04 \\
0.24\end{array}$ & $\begin{array}{l}-\overline{0} \\
0.01 \\
17 \cdot 22^{* *} \\
11.02^{*} \\
1 \cdot 19 \\
1.60 \\
7.99^{*} \\
0.92 \\
2.48\end{array}$ & $\begin{array}{l}-\overline{-} \\
0.05 \\
8 \cdot 12^{* *} \\
1.05 \\
3.70 \\
1.08 \\
2.83 \\
0.67 \\
1.67\end{array}$ & $\begin{array}{c}-\overline{1} \\
1.05 \\
48 \cdot 66^{* *} \\
18 \cdot 90 \\
9 \cdot 01 \\
5 \cdot 26 \\
10 \cdot 79 \\
0.06 \\
5 \cdot 70\end{array}$ & $\begin{array}{r}-\overline{11.45} \\
6316.86 \\
3316.04 \\
904.55 \\
1453.23 \\
6339.65 \\
1019.57 \\
2921.91\end{array}$ & $\begin{array}{c}- \\
1350 \cdot 83 \\
9214 \cdot 94 * * \\
1959 \cdot 30 \\
5805 \cdot 95 \\
2 \cdot 04 \\
1294 \cdot 43 \\
783 \cdot 54 \\
2259 \cdot 42\end{array}$ \\
\hline
\end{tabular}

${ }^{*} P<0.05 ; * * P<0.01$. 
numbers of male and female kits, total litter size/pregnant female, and female kit weight. The Dawn Pastel strain, while requiring more days to achieve mating, exhibited a higher conception rate and had larger litters than any of the mutant strains. This does not necessarily imply a genetic effect. Failure to cull poor breeders of the more popular colour strains would greatly influence results of this nature. It is also reasonable to assume that genes other than those affecting colour may affect reproductive performance. These data indicate the importance of diversification of strains to provide optimum reproductive efficiency.

The differences between the control and wheat germ oil groups were not significant for any of the characteristics studied. A highly significant $(P<0.01)$ interaction between treatments and strains for the days to achieve mating was observed (Table 2).

Treatment with EDC-WGO reduced the number of days required to achieve mating in different strains. The greatest improvement in this characteristic occurred in those strains which required a longer time to achieve mating in the control group (Dawn Pastel and Violet).

\section{ACKNOWLEDGMENTS}

The author wishes to express his appreciation to the following for the assistance provided: Noble Hall, Woodland Mink Ranch, Grand Rapids, Minnesota; Ezra Levin, Viobin Corporation, Monticello, Illinois; Stanley R. Ames, Distillation Products Industries, Rochester, New York; and J. J. Rovics, Nopco Chemical Co., Newark, New Jersey.

\section{REFERENCES}

Dukelow, W. R. \& Matalamaki, W. (1963) Effects of ethylene dichloride extracted wheat germ oil on reproductive efficiency of the sheep. (Abstract). F. Anim. Sci. 22, 1137.

Enders, R. K. (1952) Reproduction in the mink (Mustela vison). Proc. Am. phil. Soc. 96, 691.

Hansson, A. (1947) The physiology of reproduction in mink (Mustela vison, Schreb.) with special reference to delayed implantation. Acta zool. 28, 1.

Levin, E. (1963) Effects of octacosanol on chick comb growth. Proc. Soc. exp. Biol. Med. 112, 331.

Levin, E., Collins, V. K., VArner, D. S. \& Mosser, J. D. (1962) Compositions comprising octacosanol, triacontanol, tetracosanol, or hexacosanol, and methods employing same. U.S. Patent Office 3031376.

MARIon, G. B. (1962) Effects of wheat germ oil on reproductive efficiency in repeat-breeder cows. 7. Dairy Sci. 45, 904 . 